\title{
Change in HER-2/neu Status from Negative to Positive following Treatment in Breast Cancer: A Case Report
}

\author{
Lakshmi Sivarajan $^{a} \quad$ Kulumani M. Sivarajan ${ }^{b}$ \\ Joseph Natarellic Farrukh Aijaz ${ }^{\mathrm{d}}$ \\ a Vanderbilt University, Nashville, Tenn., bJoliet Oncology and Hematology \\ Associates, 'Provena St. Joseph's Medical Center, and dDepartment of Pathology, \\ Silver Cross Hospital, Joliet, III., USA
}

\section{Key Words}

Breast cancer · HER-2/neu status - Trastuzumab · Chemotherapy

\begin{abstract}
Introduction: Approximately $25-30 \%$ of breast cancers are assumed to be HER-2/neu positive. It is well known that HER-2/neu-positive cancers after treatment with trastuzumab can become HER-2/neu negative. Change in HER-2/neu status from negative to positive following treatment has not been well studied. We describe a patient with inflammatory breast cancer who was initially HER-2/neu negative but became positive after treatment. A 59-year-old postmenopausal white female saw her surgeon for violaceous discoloration of the left breast for 4 months. The surgeon palpated a mass measuring $6 \mathrm{~cm}$ in the patient's left breast. Additionally, there was violaceous discoloration involving two thirds of the breast. Biopsy of the breast mass and skin revealed inflammatory breast cancer. The tumor was estrogen receptor positive, progesterone receptor positive and HER-2/neu negative. The patient was given four cycles of chemotherapy with cyclophosphamide, doxorubicin and docetaxol. She subsequently underwent a mastectomy, excision of the skin over the chest wall and axillary node dissection. Of the axillary lymph nodes, 14/14 were involved. The tumor was still estrogen receptor positive and progesterone receptor positive, but HER-2/neu was $2+$ by immunohistochemistry and amplified at 3.3 as detected by fluorescent in situ hybridization. The patient received trastuzumab along with chemotherapy followed by radiation therapy and letrozole. She is currently receiving trastuzumab and letrozole in the adjuvant setting and appears to be doing well.

Conclusion: A breast cancer which was initially HER-2/neu negative can become positive following treatment. Therefore, re-biopsy may be necessary during the course of treatment of breast cancer to re-assess the HER-2/neu status. This gives the clinician the
\end{abstract}


opportunity to include drugs like trastuzumab and lapatinib in the treatment of patients with a transformation to HER-2/neu-positive cancer.

\section{Introduction}

It has been reported that approximately $25-30 \%$ of breast cancers are HER-2/neu positive $[1,2]$. It has previously been documented that HER-2/neu-positive cancers may become negative following treatment with trastuzumab [3]. However, transformation of cancer status from HER-2/neu negative to positive has not been widely studied. Therefore, re-assessment of HER-2/neu status in patients undergoing treatment of HER$2 /$ neu negative breast cancer is uncommon. In this case report, we describe a patient whose breast cancer changed from HER-2/neu negative to positive following treatment with chemotherapy and discuss the implications of this change on the clinical management of breast cancer.

\section{Case Presentation}

A 59-year-old postmenopausal white female noticed violaceous discoloration of her left breast for nearly 4 months prior to visiting her gynecologist. The gynecologist referred the patient to a surgeon who palpated a $6-\mathrm{cm}$ mass in the left breast and noted significant edema of the skin as well as peau d'orange appearance in the left breast. Additionally, there was left supraclavicular and left axillary lymphadenopathy. A Monopty biopsy of the left breast mass as well as a skin biopsy was done. CT scan of the chest, abdomen and pelvis revealed extensive bilateral axillary adenopathy, anterior chest wall lymphadenopathy, soft tissue edema, and inflammation of the anterior and left chest wall. The pathology of the left breast mass and skin biopsy was consistent with inflammatory breast cancer (fig. 1 , fig. 2). Her tumor was estrogen receptor positive, progesterone receptor positive and HER-2/neu negative by immunohistochemistry (1+) (fig. 3, fig. 4) and unamplified at 1.1 as detected by fluorescent in situ hybridization (FISH). The patient was treated with four cycles of chemotherapy with cyclophosphamide $\left(500 \mathrm{mg} / \mathrm{m}^{2}\right)$, doxorubicin $\left(50 \mathrm{mg} / \mathrm{m}^{2}\right)$, and docetaxol $\left(75 \mathrm{mg} / \mathrm{m}^{2}\right)$. The patient received $6 \mathrm{mg}$ s.c. pegfilgrastim the day after chemotherapy with each cycle. Although the mass decreased in size, the discoloration of the breast continued to worsen. The patient subsequently had a mastectomy, which revealed inflammatory breast cancer with 14/14 axillary lymph nodes positive for metastatic carcinoma. The patient's breast tumor was estrogen receptor positive, progesterone receptor positive and HER-2/neu positive (2+) and amplified at 3.3 as detected by FISH. The patient received trastuzumab (4 mg/kg i.v.) along with chemotherapy with paclitaxel $\left(150 \mathrm{mg} / \mathrm{m}^{2}\right)$ and gemcitabine $\left(2,000 \mathrm{mg} / \mathrm{m}^{2}\right)$ every 2 weeks. Radiation therapy was administered to the left chest wall and nodal areas $(50 \mathrm{~Gy})$ as well as to the mastectomy scar $(60 \mathrm{~Gy})$. The patient completed her postoperative chemoradiotherapy and is currently on trastuzumab and letrozole $2.5 \mathrm{mg}$ p.o. daily.

\section{Discussion}

This case indicates the possibility that an initially HER-2/neu-negative breast cancer can become HER-2/neu positive following treatment with chemotherapy. Breast cancer is well known to be heterogeneous and it is possible that the initial biopsy may have been negative due to sampling error and that only the mastectomy specimen revealed the true HER-2/neu status of the neoplasm ( $\underline{\text { fig. }} \mathbf{5}, \underline{\text { fig. }}$ ). Another possible explanation is that the chemotherapy preferentially reduced the burden of the HER-2/neu-negative component in the breast cancer while permitting growth of the HER-2/neu-positive component. 


\begin{tabular}{r|l|l|l}
$\begin{array}{c}\text { Case Reports in } \\
\text { Oncology }\end{array}$ & $\begin{array}{l}\text { Case Rep Oncol 2011;4:19-24 } \\
\text { DOl: 10.1159/000324114 }\end{array}$ & $\begin{array}{l}\text { Published online: } \\
\text { January 18, 2011 }\end{array}$ & $\begin{array}{l}\text { O 2011 S. Karger AG, Basel } \\
\text { ISSN 1662-6575 } \\
\text { www.karger.com/cro }\end{array}$ \\
\hline
\end{tabular}

Regardless of the mechanism of this transformation, a change in cancer status from HER-2/neu negative to positive has important clinical implications. Had this change in HER-2/neu status not been identified following the mastectomy, this patient would not have been offered trastuzumab treatment, which markedly improves survival of patients with HER-2/neu-positive breast cancers [4]. Recent research has demonstrated that conversion from HER-2/neu negative to positive can occur in up to $3.5 \%$ of the cases [5]. However, this has not often been reported. As a result, patients with HER-2/neu-negative breast cancers are not commonly re-biopsied to assess change in status. This case demonstrates that in patients with worsening condition despite chemotherapy, reassessment of the HER-2/neu status may be justified.

\section{Conclusion}

In this report we have shown that HER-2/neu-negative breast cancers can become positive following treatment. In patients with breast cancer (even metastatic) who are not responding to treatment, it may be reasonable to re-biopsy to assess their HER-2/neu status. Although transformation of HER-2/neu status from negative to positive may be uncommon, the changed status may open up new avenues of treatment like trastuzumab or lapatanib. These treatments would not be offered without re-assessment of the HER$2 /$ neu status.

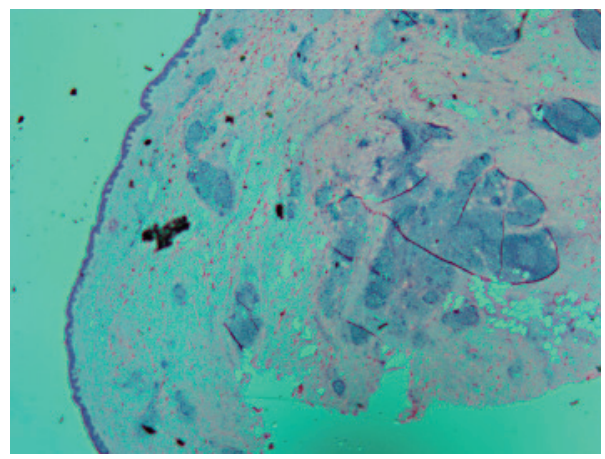

Fig. 1. This is a low-power view of the skin from the core biopsy showing clusters of breast carcinoma cells. Hematoxylin and Eosin. 


\begin{tabular}{c|l|l|l}
$\begin{array}{c}\text { Case Reports in } \\
\text { Oncology }\end{array}$ & $\begin{array}{l}\text { Case Rep Oncol 2011;4:19-24 } \\
\text { DOI: 10.1159/000324114 }\end{array}$ & $\begin{array}{l}\text { Published online: } \\
\text { January 18, 2011 }\end{array}$ & $\begin{array}{l}\text { O 2011 S. Karger AG, Basel } \\
\text { ISSN 1662-6575 } \\
\text { www.karger.com/cro }\end{array}$ \\
\hline
\end{tabular}

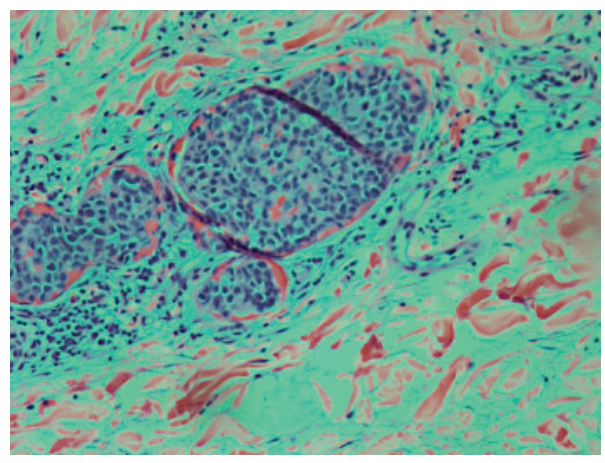

Fig. 2. This is a high-power view of the breast carcinoma cells within the dermal blood vessels. Hematoxylin and Eosin.

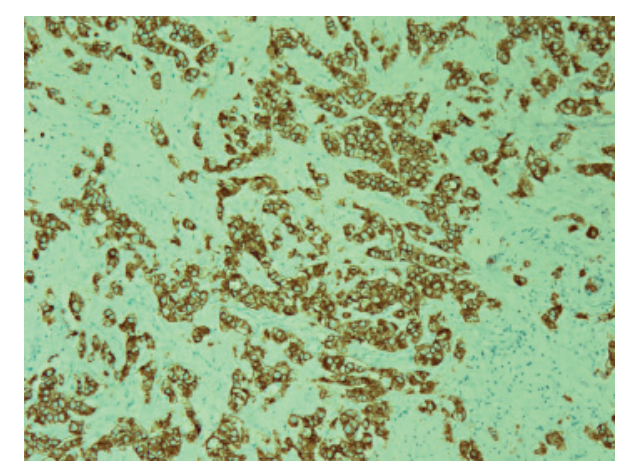

Fig. 3. This is a low-power image of the positive control slide for HER-2/neu. Cells staining gold amplify HER-2/neu. HER-2/neu immunohistochemistry stain.

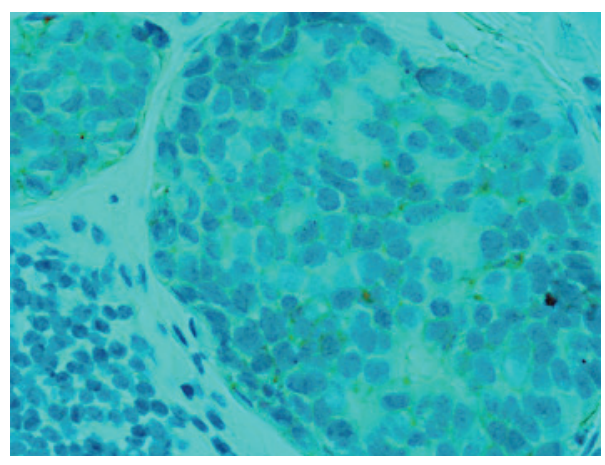

Fig. 4. This is a high-power image of the breast carcinoma cells in the skin showing a negative reaction for HER-2/neu. HER-2/neu immunohistochemistry stain. 


\begin{tabular}{c|l|l|l}
$\begin{array}{c}\text { Case Reports in } \\
\text { Oncology }\end{array}$ & $\begin{array}{l}\text { Case Rep Oncol 2011;4:19-24 } \\
\text { DOI: 10.1159/000324114 }\end{array}$ & $\begin{array}{l}\text { Published online: } \\
\text { January 18, 2011 }\end{array}$ & $\begin{array}{l}\text { O 2011 S. Karger AG, Basel } \\
\text { ISSN 1662-6575 } \\
\text { www.karger.com/cro }\end{array}$ \\
\hline
\end{tabular}

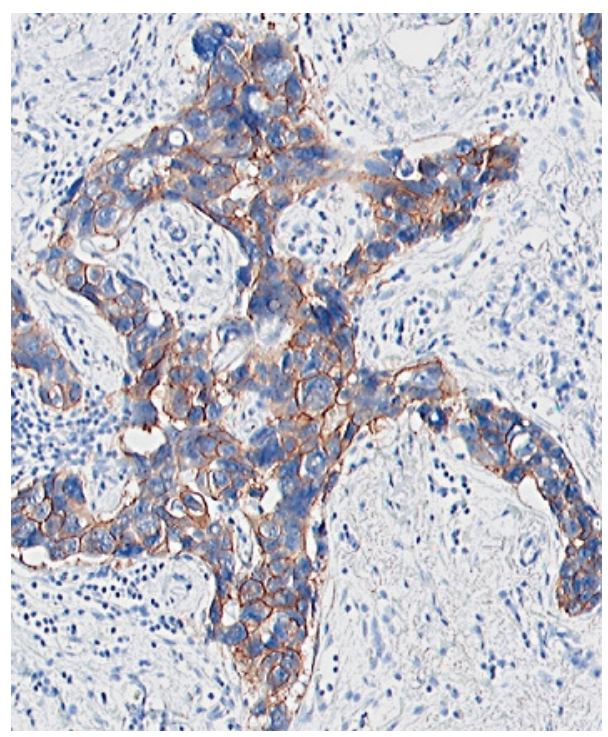

Fig. 5. This is a low-power view of the breast carcinoma cells in the skin showing a positive reaction for HER-2/neu. HER-2/neu immunohistochemistry stain.

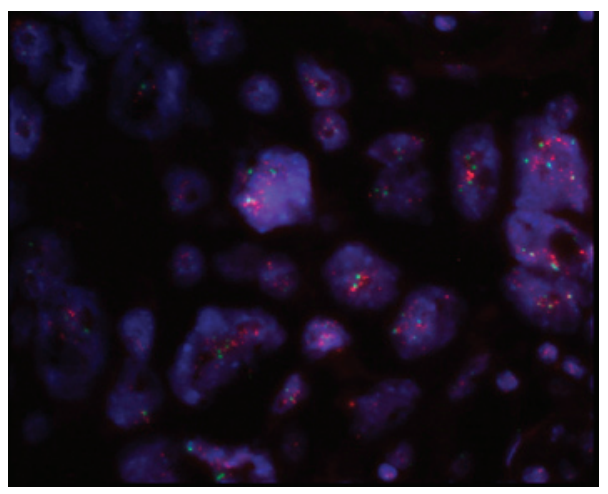

Fig. 6. Following mastectomy, HER-2/neu is positively amplified at 3.3. FISH. 


\section{References}

1 Chang HR: Trastuzumab-based neoadjuvant therapy in patients with HER2-positive breast cancer. Cancer 2010;116:2856-2867.

2 Slamon DJ, Clark GM, Wong SG, Levin WJ, Ullrich A, McGuire WL: Human breast cancer: correlation of relapse and survival with amplification of the HER-2/neu oncogene. Science 1987;235:177-182.

-3 Mittendorf EA, Wu Y, Scaltriti M, Meric-Bernstam F, Hunt KK, Dawood S, Esteva FJ, Buzdar AU, Chen H, Eksambi S, Hortobagyi GN, Baselga J, Gonzalez-Angulo AM: Loss of HER2 amplification following trastuzumab-based neoadjuvant systemic therapy and survival outcomes. Clin Cancer Res 2009;15:7381-7388.

-4 Romond EH, Perez EA, Bryant J, Suman V, Geyer CE, Davidson NE, Tan-Chiu E, Martino S, Paik S, Kaufman PE, Swain SM, Yothers G, Jenkins RB, Brown AM, Dakhil SR, Mamounas EP, Lingle WL, Klein PM, Ingle JN, Wolmark N: Trastuzumab plus adjuvant chemotherapy for operable HER2-positive breast cancer. N Engl J Med 2005;353:1673-1684.

-5 Hirata T, Shimizu C, Yonemori K, Hirakawa A, Kouno T, Tamura K, Ando M, Katsumata N, Fujiwara Y: Change in the hormone receptor status following administration of neoadjuvant chemotherapy and its impact on the long-term outcome in patients with primary breast cancer. Br J Cancer 2009;101:1529-1536. 